\title{
LIQUIDITY AND SOLVENCY OF HEALTHY AND BANKRUPT ENTITIES: DO FINANCIAL STATEMENTS SHOW ANY DIFFERENCES?
}

\author{
OBRADOVIĆ Ana1, MIZDRAKOVIĆ Vule², OBRADOVIĆ Maja ${ }^{3}$ \\ ${ }^{1}$ Singidunum University, Belgrade (SERBIA) \\ ${ }^{2}$ Singidunum University, Belgrade (SERBIA) \\ ${ }^{3}$ Singidunum University, Belgrade (SERBIA) \\ Emails:aobradovic@singidunum.ac.rs; vmizdrakovic@singidunum.ac.rs; mobradovic@singidunum.ac.rs
}

\begin{abstract}
The aim of this paper is reflected in the analysis of the connection between the financial operations presented in companies' financial statements and the fact whether bankruptcy proceedings have been initiated against the observed companies. Namely, the fundamental indicators of a company's business success, including liquidity and solvency, are of immense significance for all stakeholders, and can also be used to predict the probability whether bankruptcy proceedings will be opened. Bankruptcy authorities make the decision to initiate bankruptcy proceedings, not solely on the basis of the results presented in the financial statements, but predominantly on the basis of the reasons defined by law. However, the question arises whether the fact that bankruptcy proceedings have been initiated correlates with the financial situation as shown in the financial statements. The paper's research sample is made up of the financial reports of two groups of companies, the first group of which includes all the companies in the Republic of Serbia that initiated bankruptcy proceedings in 2019, while the second group consists of randomly selected "healthy" companies. By applying two variables, i.e., liquidity and solvency, we are witnessing a difference in the results of the healthy versus the bankrupt companies. Healthy companies are largely liquid and solvent (47\%), but it can be noticed that a number of healthy companies have problems with liquidity. Bankrupt companies are faced with a high liquidity risk, while a small number of them face the problem of insolvency.
\end{abstract}

Keywords: financial performance, current ratio, debt ratio, risk

JEL: G21

UDC: $\mathbf{6 5 7 . 4 2 2}$

659.233

COBISS.SR-ID 28653065

\section{Introduction}

The analysis of healthy and bankrupt companies' operating activitiesusing financial reports has long been the authors'prime focus. The initial research mainly centered on the prediction for initiating bankruptcy proceedings, i.e., assessing the probability of bankruptcy. Taking into consideration the costs of the procedure and the high probability of loss of value (capital), the goal of these researches is evident. A large number of studies [1], [2], [3] indicate that it is possible to quite successfully predict the initiation of bankruptcy proceedings much earlier 
(three years) before it actually takes place, on the basis of publicly disclosed financial statements. In keeping with the initial models that are based ondata from legal entities in the United States, different models were developed later on using data from other countries, industries, sectors, time periods and which therefore cannot be generalized [4].

However, the initiation of bankruptcy proceedings in a legal entity will depend primarily on the legal regulations of the state in which it performs economic activity. It may happen that the same legal entity is able to perform its economic activitysmoothly in one economic environment, whereas at the same time it would face bankruptcy proceedings in another. In that sense, the legal reasons for initiating bankruptcy proceedings are of tremendous importance, because the bankruptcy judge, based on them, considers whether they are fulfilled on a specific legal entity and decides to initiate bankruptcy proceedings. For instance, some of the most common reasons for initiating bankruptcy proceedings defined in the legal regulations around the globe include: difficulty to settle liabilities as they become due (ability to pay solvency test), the assessment of balance sheet solvency (balance sheet solvency test) and the issue of legal entity's capital adequacy (the capital adequacy solvency test) [5]. The provisions of the Law on Bankruptcy of the Republic of Serbia define the following reasons: over-indebtedness, permanent insolvency, pending insolvency; and failure to comply with the adopted reorganization plan or if the reorganization plan was put into effect in a fraudulent or unlawful manner [6]. However, if we observe and analyze the company's operating activitiesbased on published financial statements, which should demonstrate a realistic picture of its performance, we can see that some companies meet the reasons for initiating bankruptcy proceedings from the legal point of view, while performing their activities unhindered. Naturally, we can have a reverse situation, i.e., that the observed legal entity goes into bankruptcy, and that the financial statements show that its operating activities are not endangered. There are various explanations as to why such situations are possible, including: misleading and falsified financial statements, strategic bankruptcy, inadequate legal regulations, inefficiency of judicial bodies, the policy of "sparing" strategically important companies and others. However, the operating activities of the company as observed through its published financial statements should indicate the fact that the company is undergoing bankruptcy proceedings, despite the previously listed exceptions.

The aim of this paper is to check whether the aforestated is true when it comes to companies from the Republic of Serbia. The contribution of this paper is reflected in the application of research results in future research related to predicting the initiation of bankruptcy proceedings in the Republic of Serbia and the countries with similar economic characteristics. Namely, the basic premise of these researches is the correlation between the financial situation in the company from the aspect of legal regulations in the field of bankruptcy proceedings and the presentation of its operations in financial statements. The next part of the paper contains an overview of the relevant literature, while the subsequent two parts present the methodology and research results. At the end of the paper, conclusions will be made and directions for future research presented.

\section{Literature Review}

The review of the relevant literature can be divided into several parts, first of all, papers dealing with predicting the probability forinitiating bankruptcy proceedings, then indicators for assessing the liquidity and solvency of healthy and bankrupt companies; and papers dealing with the analysis of factors influencing companies' emerging from bankruptcy. The first paper from the first group dates back to 1930 and is in fact a report made by the Bureau of Business Research (BRR). Until 1965, research was very similar [7], [8], [9], [10]. 
However, the idea that the simultaneous analysis of multiple financial indicators can increase the predictive power of bankruptcy was developed by Professor Beaver [11].

Subsequent research was quite similar to the aforementioned and was done for different countries as well as for different industrial sectors [1], [12], [13]. In nearly all research, the conclusion is that an increase in indebtedness leads to an increase in the probability of initiation of bankruptcy proceedings, while liquidity is negatively correlated.

When it comes to research from the Republic of Serbia, which relates to the assessment of solvency and liquidity of legal entities, we may conclude that the solvency and liquidity of companies is quite endangered [14], [15]. The same authors state in another study that the amount of debt-to-equity ratio of Serbian companies is significantly above the reference value of 1 and ranges between 2.01, 2.48, 3.01 and 1.96, for the period 2008-2011 [14].

As regards research related to the factors that influence companies exiting the bankruptcy process, the authors point out that companies that do not recover have a significant amount of liabilities, including discretionaryaccruals. In addition, companies that improve their position through reorganization are mainly those that were large legal entities before the bankruptcy was initiated, and at the same time solvent [16], [17].

\section{Research methodology}

The paper research is founded on companies' financial statements for 2018 as a reporting period. The research sample can be divided into two parts, i.e., the companies that are bankruptcy debtors, where the bankruptcy procedure was initiated in the period from 01/01 to $31 / 12 / 2019$ and healthy companies (where bankruptcy proceedings have not been initiated yet). Data on the bankruptcy proceedings initiatedduring the observed period were downloaded from the official website of the Republic of Serbia Agency for Licensing Bankruptcy Trustees. In the course of the observed period, there were a total of 448 bankruptcy proceedings. Nevertheless, bearing in mind that financial reporting varies depending on the size of the legal entity, the research focused on small, medium and large legal entities. There was a total of 209 such legal entities and therefore the initial sample of bankrupt companies was reduced to that number. In keeping with the aforesaid, the same number of (healthy) legal entities in which no bankruptcy procedure was initiated (209 legal entities) were selected randomly. Financial reports were obtained for the sampled companies so that they corresponded to the observed reporting period after which financial indicators were calculated based on which it is possible to assess the companies' liquidity and solvency.

This research will use the ratio number Acid test for the purpose of assessing liquidity. In relation to the current ratio, which is most frequently used in research to predict the probability for initiatingbankruptcy proceedings, the Acid test shows a more realistic picture of the company's liquidity because it excludes the value of goods, finished products, work in progress and materials the company has in stock. Namely, it takes a significantly longer period of time for these funds to become money in relation to receivables or securities that the company may own. Bankruptcy debtors usually have a very small amount of money at their disposal, and on the other hand, they can have a significant value of stocks that are obsolete and that should have been taken out of stock. Therefore, we can expect that the acid ratio will give a much more realistic picture of the liquidity of companies and will be used as a basic indicator in this paper. Authors Bryan, Tiras, \& Wheatley (2002) conclude that inventories of bankrupt business entities turn slower and that the current ratio will be less likely to be a proper conduct of liquidity level of those entities. The expected value of this ratio is 1 and this limit will be used to classify companies into those that are (liquid) capable of settling shortterm liabilities in the short period of time without jeopardizing further operating activities and those that are unable to do so (illiquid). The basic prerequisitesto ensure the solvency of a 
company include an adequate amount of capital and an assessment of the risk level of the company's assets [18]. The most frequently used ratio number for assessing solvency is the debt ratio. This number represents the ratio between the total liabilities of the company and its total assets, i.e., the company's property. Even though there are no difficulties in calculating this ratio, its interpretation can be problematic because there is no generally accepted limit to its value, as is the case with the acid ratio. Therefore, in this study, solvent and non-solvent companies will be distinguished by debt ratio of 0.75 (75\%). It aforementioned was determined based on the research conducted by the authors Stanisic, Radojevic, Mizdrakovic and Stanic in 2012, using the sample of 53,996 companies from Serbia [19]. That research showed that there was a significant increase in the percentage of bankrupt entities when the debt ratio stood between 0.7 and 0.8 .

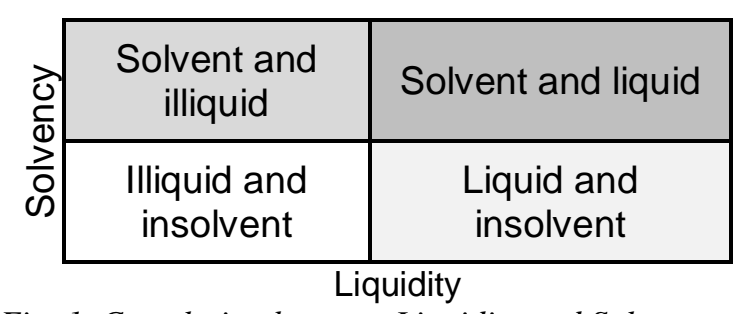

Fig. 1. Correlation between Liquidity and Solvency

The expected position of healthy business entities is a quadrant that shows liquid and solvent legal entities, whereas when it comes to bankrupt legal entities, they are expected to be primarily illiquid and insolvent (although they can be found in other quadrants, depending on the reason why the procedure was initiated).

\section{Research results}

The results of the research are shown in the graphs below. Figure 2 shows both groups of observed companies, where the largest number of them $(36.36 \%)$ is in the first quadrant (152 out of 418). This means that these legal entities have a liquidity problem, but in the long run they have enough funds to settle their long-term payables. The rest of the companies are mostly in the third quadrant $(28.7 \%)$ and they are both illiquid and insolvent companies that should be undergoing bankruptcy proceedings. When we separate legal entities according to whether they are undergoing bankruptcy proceedings or not, we get a clearer picture of their financial position.

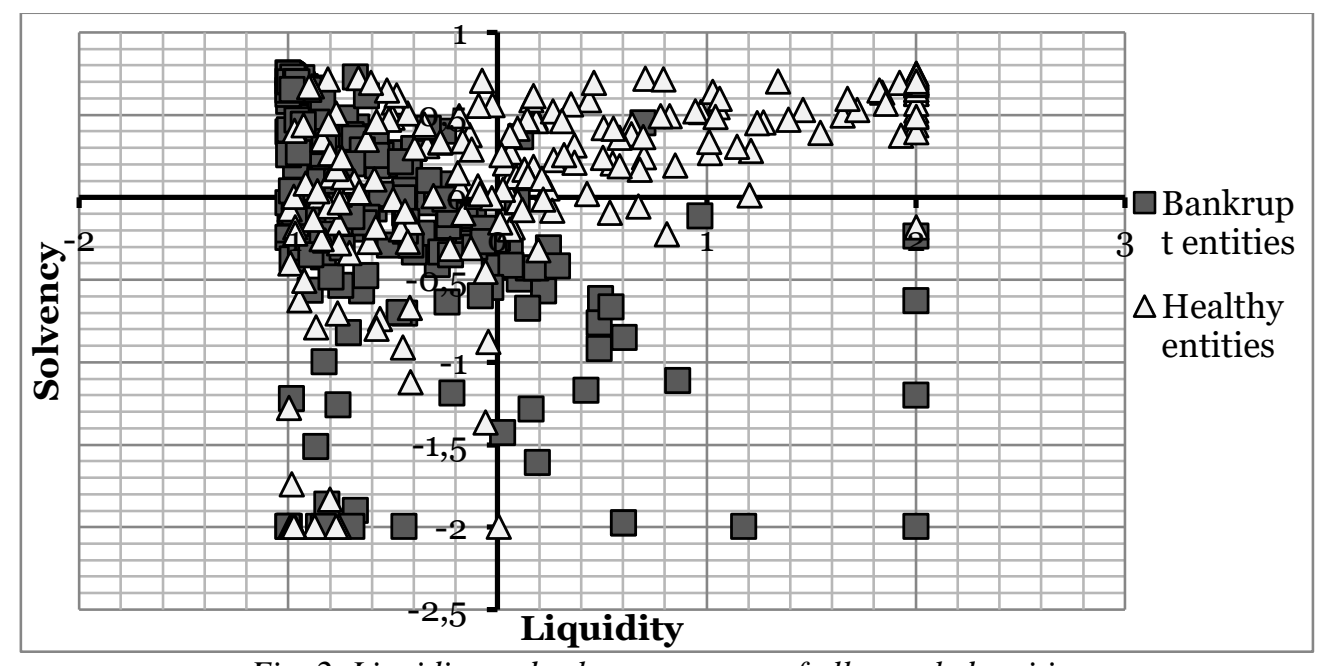

Fig. 2. Liquidity and solvency groups of all sampled entities

Source: Authors' data

${ }^{\circ}$ Filodiritto Editore 
Based on the conducted analysis, it can be concluded that almost half of healthy legal entities (99 out of 209) are located in the expected quadrant - the quadrant of liquid and solvent companies. Based on Figure 3, 46\% of healthy companies have liquidity-related problems, while $28 \%$ of healthy companies have problems maintaining long-term liquidity.

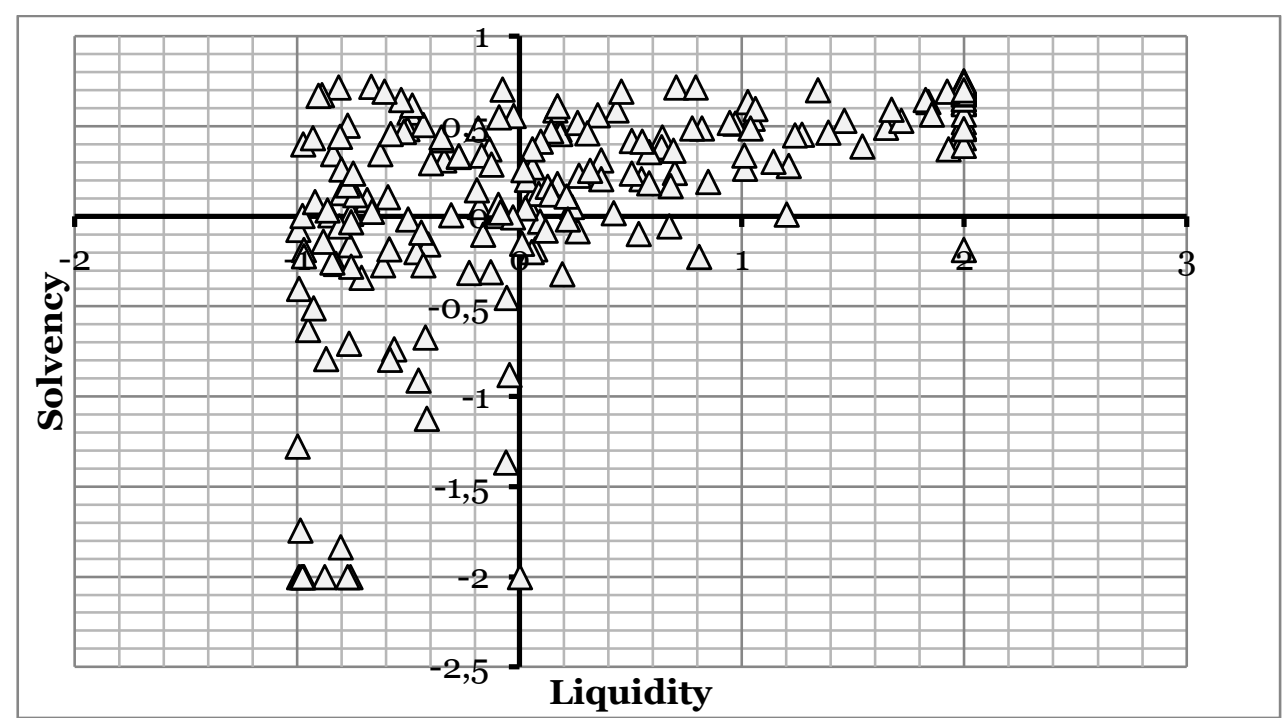

Fig. 3. Liquidity and solvency of healthy entities

Source: Authors' data

The results of the research show a certain deviation from the set assumptions when it comes to bankrupt companies. In this group of companies, the largest share belongs to solvent legal entities that have liquidity problems (48\%). When we analyze bankrupt companies, only two, which is less than $1 \%$ of those sampled, are liquid and not over-indebted (Figure 4). It can be assumed that these are companies that have decided to initiate bankruptcy proceedings for strategic reasons (avoidance of court disputes, settlement of obligations, etc.).

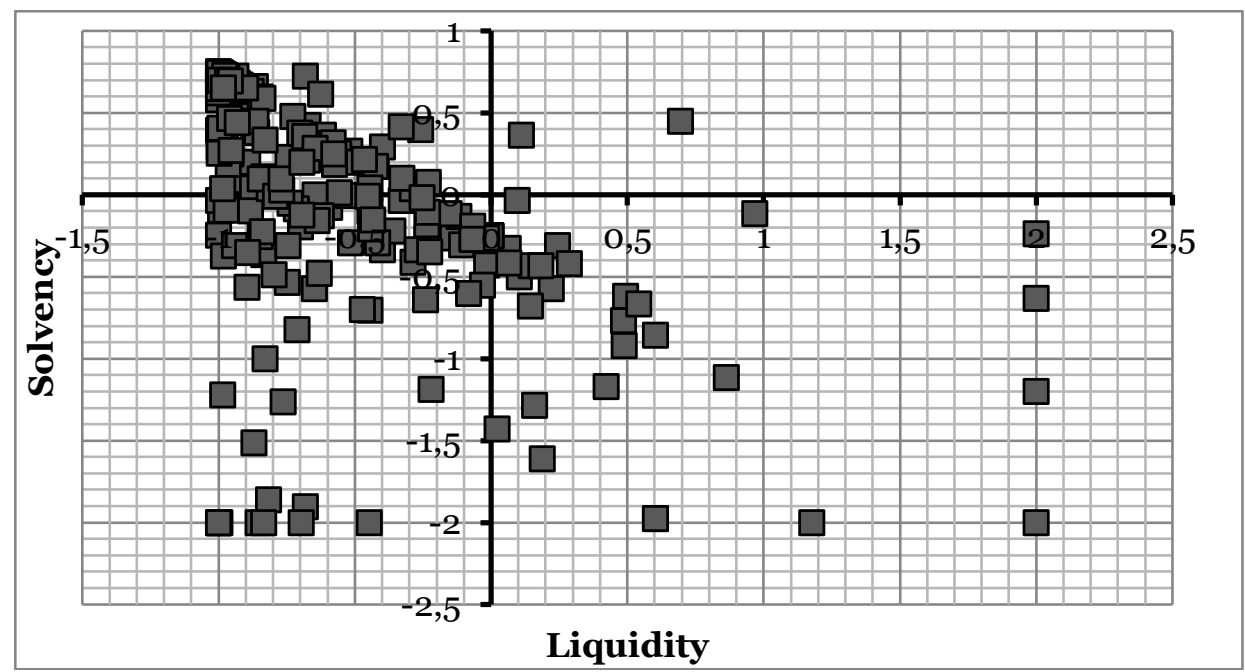

Fig. 4. Liquidity and solvency of bankrupt entities

Source: Authors' data

\section{Conclusion}

The subject of this paper was the financial statements of 418 companies, which for the sake of the analysis were divided into two groups, with equal participation of companies in each group. Based on the conducted research and the presented results, it can be noticed that the 
data presented in the financial statements of the companies undergoing bankruptcy indicate the initiation of a bankruptcy procedure. This is evidenced by the fact that almost $99 \%$ of the analyzed companies undergoing bankruptcy proceedings experience problems with liquidity and/or solvency. This information is certainly important from the aspect of future research regarding predictions of the probability of bankruptcy proceedings initiation. The analysis of the financial statements of healthy companies showed that $47.36 \%$ of these companies are defined as solvent and liquid. Nevertheless, a significant number (110 of 209) of legal entities in this group are faced with a high risk of liquidity and/or over-indebtedness. The aforestated actually explains the fact that almost all models for predicting the initiation of bankruptcy proceedings are far more precise in classifying bankrupt in relation to healthy companies.

There are two explanations for the previous situation, either the bankruptcy proceedings in the Republic of Serbia are initiated too late, or the financial statements show the first signs that the company is ready for bankruptcy proceedings, much earlier than can be confirmed in court proceedings. The focus of future research could be on making a comparative analysis of companies from different legal systems (those aimed at protecting creditors and those aimed at protecting the bankruptcy debtor) and a detailed analysis of the reasons for initiating bankruptcy proceedings and the financial position shown in the financial statements.

\section{REFERENCES}

[1] E. Altman, "Financial Ratio, Discriminate Analysis and Prediction of Corporate Bankruptcy", Journal of Finance, 23(4), pp. 589-629, 1968.

[2] J. Ohlson, "Financial Ratios and the Probabilistic Prediction of Bankruptcy", Journal of Accounting Research, t. 18, br. 1, pp. 109-131, 1980.

[3] G. Kane, F. Richardson i P. Graybeal, "Recession-Induced Stress and the Prediction of Corporate Failure", Contemporary Accounting Research, t. 15, br. 1, pp. 631-650, 1996.

[4] N. Bărbuţă-Mişu i M. Madaleno, "Assessment of Bankruptcy Risk of Large Companies: European Countries Evolution Analysis", Journal of Risk and Financial Management, t. 13, 2020.

[5] J. Heaton, "Solvency Tests", The Business Lawyer, t. 62, br. 3, pp. 983-1006, 2007.

[6] “Sl. glasnik RS”, br. 95/2018, 2018. [Na mreži]. Available: https://www.slglasnik.com/. [Poslednji pristup 8 September 2020].

[7] P. FitzPatrick, "A Comparison of Ratios of Successful Industrial Enterprises with Those of Failed Companies", The Certified Public Accountant, 6(1), pp. 727-731, 1932.

[8] R. Smith i A. Winakor, "Changes in Financial Structure of Unsuccessful Industrial Corporations", Bureau of Business Research, 51(1), pp. 3-44, 1935.

[9] C. Merwin, Financing Small Corporations in Five Manufacturing Industries, 1926-1936, New York: National Bureau of Economic Research, 1942.

[10] N. Jackendoff, A Study of Published Industry Financial and Operating Ratios, Philadelphia: Temple University, Bureau of Economic and Business Research, 1962.

[11] W. Beaver, "Financial Ratios as Predictors of Failure", Journal of Accounting Research, 4(1), pp. 71$111,1966$.

[12] E. Altman, A. Danovi i A. Falini, "Z-Score Models' Application to Italian Companies Subject to Extraordinary Administration”, Journal of Applied Science, 23(1), pp. 128-137, 2013.

[13] J. Bauer i V. Agarwal, "Are Hazard Models Superior to Traditional Bankruptcy Prediction Approaches? A Comprehensive Test”, Journal of Banking and Finance, 40(1), pp. 432-442, 2014.

[14] S. Sljivic, D. Vojteski-Klijenak i M. Pavlovic, "Solvency and Profitability of Serbian Industry", International Review, 1(1-2), pp. 29-50, 2013.

[15] N. Kaludjerovic, S. Stanojevic i M. Ljubic, "Hidden Losses in Financial Reporting and the Manner of Hiding Case Serbia - Part Two", International Review, 4(1-2), pp. 125-141, 2016.

[16] E. Rose-Green, "The Relationship between Firms' Characteristics in the Periods Prior to Bankruptcy Filing and Bankruptcy Outcome”, Accounting and Finance Research, 2(1), pp. 97-109, 2013.

[17] D. Bryan, S. Tiras i C. Wheatley, "The Interaction of Solvency with Liquidity and its Association with Bankruptcy Emergence", Journal of Business Finance and Accounting, t. 29, br. 7, pp. 935-965, 2002.

[18] L. Lukic i M. Trisic, "Risk Management and Yield Management in Banks", Trendovi u poslovanju, 5(1), pp. 29-40, 2015. 
[19] N. Stanišić, T. Radojević, V. Mizdraković i N. Stanić, "Capital efficiency analysis of Serbian companies”, Singidunum revija, t. 9, br. 2, pp. 41-49, 2012.

\section{Article history:}

Received 22 September 2020

Accepted 5 December 2020 